\title{
STUDIES ON THE ARCHAEOLOGY OF THE NETHERLANDS ANTILLES: I
}

\section{NOTES ON THE POTTERY OF ARUBA, CURAÇAO AND BONAIRE}

For more than eighty years the Dutch islands off the north coast of Venezuela have aroused the archaeological interest of a few people, whose work the government has failed to appreciate. Whenever an appeal was made to the competent authorities in the home country to try to cast more light on the past of the islands under its rule, a barrier of bureaucratic dilatoriness and amiable misunderstanding was encountered, and hence the few ardent advocates of the Antillean cause should not be blamed for not having managed to elevate archaeological knowledge of the region to a respectable level.

Moreover, none of the persons concerned has been a professional archaeologist. Father. A. J. van KoolwIJK cannot be described as such, and nor can Professor J. P. B. DE Josselin DE JoNG. However, the latter, though really an ethnologist and linguist, is entitled to be called an archaeologist on account of his careful and scientific methods. Dr. P. WagenaAR HummeLINCK is not a trained archaeologist either; as a zoologist, he naturally has quite another sphere of activity. But his manysided love for the islands has also made him an indefatigable champion of the cause of archaeology there.

The National Museum of Ethnology (Rijksmuseum voor Volkenkunde) at Leiden now has an extensive collection of archaeological specimens which has been amassed by the above-mentioned persons. ${ }^{1}$

Since van KoolwiJk's material has already been published bij DE JosSELIN DE JoNG, we have mainly paid attention to the

1 Hummelinck not only did collecting work himself, but also obtained material from several other sources, such as the Dominican Fathers in Bonaire; A. D. Ringma (Curaçao and Aruba); Dr. A. C. J. Burgers (Bonaire); and G. Bogatrs (Aruba). 


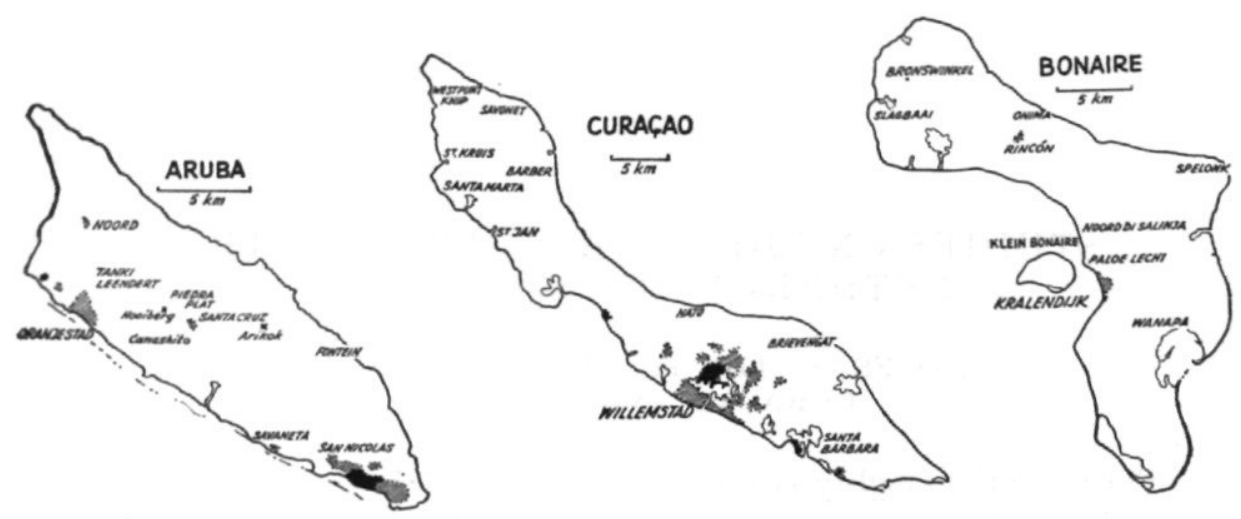

Fig. 1 Sketchmap of the Islands Aruba, Curaçao and Bonaire, showing localities mentioned in the text.

latter two collections, about which nothing has yet made known.

Preparation of this material raised many problems. We received it with but little information, which did not enable us to get a correct idea of its archaeological context. Stratigraphic data were completely absent, and it is precisely these which are so important to investigation of a site, to enable the various periods of occupation and their relative ages to be determined. Even if the site concerned has had only one period of habitation, the stratigraphic situation of the specimens nevertheless remains important in that they will show us at any rate the initial and final dates of settlement.

The archaeology of our three islands at once makes special demands in this respect. The comparatively one-sided development of the Indian population and, on the other hand, the nature of the soil (i.e. erosion and, in particular, the insignificant thickness of the concentrations of shells) render stratigraphy well nigh out of the question.

Hence it must have been impossible for DE Josselin DE JoNG, when digging at Santa Cruz, Aruba, in I923, to see where exactly the virgin soil began; where the old surface line (i.e. the stratum on which the historical population lived) was; and in what relation to these strata the potsherds or other objects were found. Moreover, in many places the soil had been ploughed, and consequently it is highly probable that nothing is lying in its original place, or has been lying there since the first excavation. Anyway, he had the sherds carefully put away and classified in large drawers. As regards the site at Santa Cruz, where he dug in 


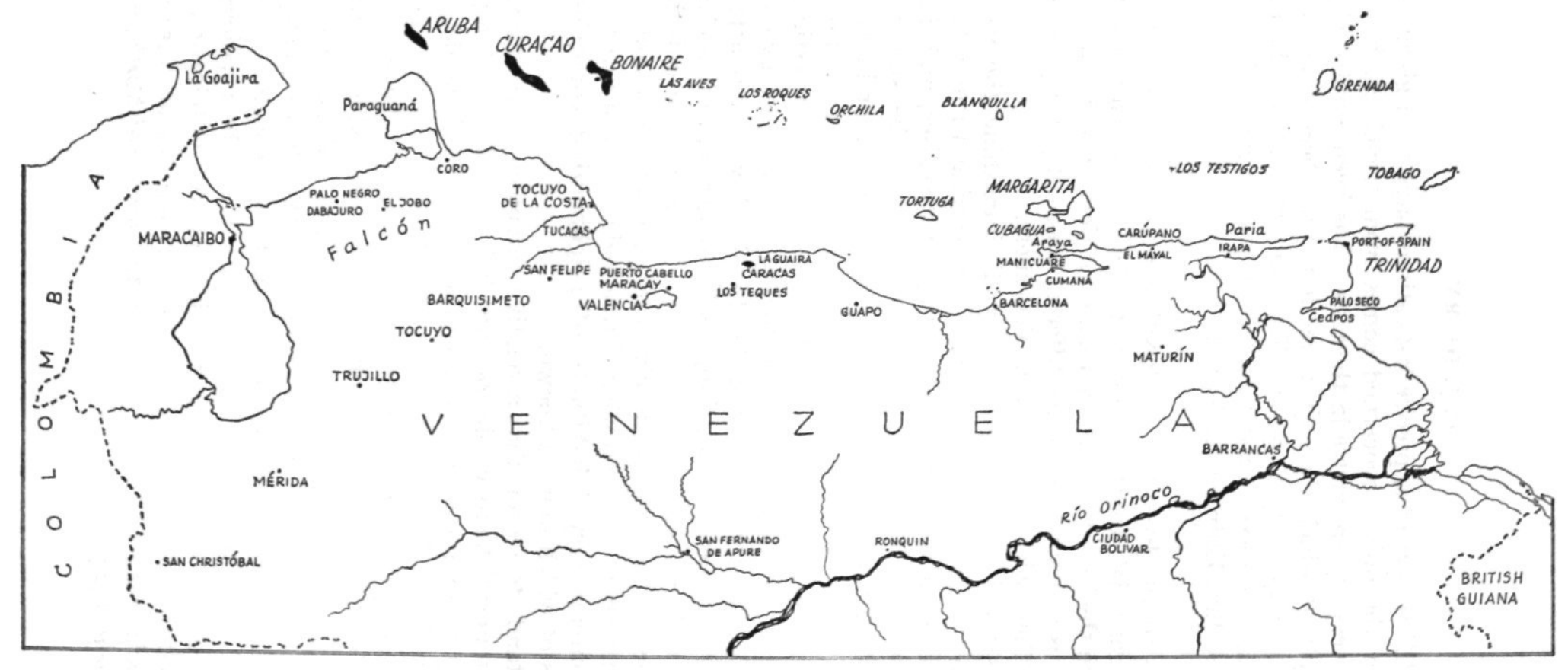

Fig. 2 Sketchmap of northern and middle Venezuela, showing localities mentioned in the text. 
three different places, precise indications have been given as to whether the object concerned comes from trench A, B or C, while every square metre in the trench has been numbered and the depth at which the object was found has been indicated as either 0 to 25 or 25 to $50 \mathrm{~cm}$. The same obtains for the other sites that were excavated by him, such as Savaneta in Aruba and Sint Jan, Knip and Asiento in Curaçao.

Thanks to DE Josselin DE Jong's description of VAN KooLwIJK's material (I9I8), and owing to the long-known connection between the islands and the mainland of Venezuela, it was possible for us to try to group the different kinds of pottery by comparing them with material from Venezuela.

We started our investigation by distinguishing the various earthenware utensils and by carefully sorting them into, for instance, figurines, amulets, griddles, pottery discs, and finally ordinary domestic crockery, which may itself be subdivided into different sorts. In archaeology, in most cases, and certainly in this particular case, pottery is the most important startingpoint for a historical reconstruction of the area to be investigated.

Accordingly, we tried to draw up a relative chronology on the basis of the pottery. With the aid of the sherds we had to attempt to ascertain whether, and, if so, in what sequence, various civilizations had followed one another, or, if there could only have been one single continuous civilization, what important facts are conspicuous in it and what chronological relations were with the contemporary inhabitants of neighbouring countries or regions of which more is known.

It stands to reason that a relative chronology gives no more than an unsatisfactory solution. But it is an indispensable preliminary to an absolute chronology, which can and should only be based upon datings by means of radioactive carbon, pollen analysis or glottochronological determinations of dates.

In establishing our relative chronology we started from various factors, viz.: historical correlations, which did not carry us farther back than the Spanish conquest of the islands; geological and geomorphological correlations; probable economic circumstances; trade and dissemination; and finally the typology of the pottery. In this we relied mainly on the publications by C. OSGOOD \& G. D. HowARD: An Archaeological Survey of Venezuela, I943, and A. KIDDER II: Archaeology of Northwestern Venezuela, 1944 . 
The publication of An Archaeological Chronology of Venezuela, by J. M. CRUXENT \& IRving Rouse, I958, provided us with a splendid amplification of our preparatory work, enabling us to adopt the authors' absolute chronology and fit it into the frame of the archaeology of our islands.

In our typological investigation of the pottery we tried to find a certain evolutionary line in the composition of the material, in the technique of its manufacture, and in the different types of decoration. But this approach is fraught with various risks. One is easily inclined to consider coarse pottery older than that which is more delicate and perhaps more beautiful. The contrary, however, may be true. The older pieces of pottery found in Aruba proved to be of finer texture than the examples of more recent date. Comparison showed that the older sherds belong to a type frequently found along the northeast coast of Venezuela, and so we suppose that the most ancient pottery was imported, and that it was not until later the natives of the islands started to bake their own. Here is a connection with the commercial relations we needed for our relative chronology. If we were to exclude the influence of trade, and were to assume that all the pottery found in Aruba was made locally, the degeneration observed in the pottery would lead to the conclusion that an ancient, highly developed population had been ousted by a newer, less civilized one.

However, exclusion of the influence of trade is a hypothesis which is difficult to maintain, because then it would have to be assumed that the inhabitants of Aruba and of the northeast coast of Venezuela made practically identical pottery perfectly independently of one another. Besides, numerous excavations in Venezuela have proved that the nidus of the kind of pottery that will be described in this article was situated in the eastern part of the country. We therefore believe that in remote times the islands traded with northeast Venezuela.

We are still left with the problem of the population groups. If the fact of trading is taken into consideration, it is improbable that a more highly developed group was superseded by a less civilized one; the reverse might have taken place. This is an extremely difficult problem, and the ethnologists offer us little help in trying to solve it. The ancient commercial pottery, which must have been more or less contemporaneous with the shell artifacts found in the islands, argues in favour of a primitive fishing folk which was suddenly disturbed by a more recent 
group from the mainland who brought agriculture and pottery with them (cf, van HeEKEREN's paper, p. IIO).

Finally, in drawing up our relative chronology, we have made use of certain geological and climatological synchronisms. When a further investigation of the islands is carried out, it would be advisable also to study correlations obtained by means of palynology. We only have historical data from the time after the conquest by the Spaniards, that is to say since $\mathbf{I}_{500}$. And, with a few exceptions, these recent data have been of little use to us in studying the pottery, because they have not always proved to be trustworthy.

All the above factors gradually shape a fixed pattern in archaeology for the formulation of a relative chronology, the necessary basis for an absolute chronology built up with the aid of modern technical means.

It is CRUXENT and Rouse's great merit that, after long and careful collaboration, with a profound knowledge of their subject, they were the first to give an absolute chronology for Venezuela which is perfectly acceptable in the present state of archaeological knowledge of the northern part of South America. They (I958, p. 8) based their findings on five factors, viz.:

I) Rate of refuse accumulation, e.g. the amount of time required for disposal of the refuse of each period.

2) Glottochronology.

3) Radiocarbon dating.

4) Geological correlations.

5) Historical correlations.

Elaboration of the foregoing led to a division into five periods, as may be seen in the following table on page 87 (CRUXENT \& Rouse, I958, p. 9).

Seeing that the archaeology of our islands is so closely connected with that of Venezuela, we may now try to fit our material into the scheme of the above-mentioned authors. ${ }^{1}$ CRUXENT \& Rouse have classified all the archaeological material finds in Venezuela in ten main styles, called series, and they selected (p. 23) "the most elaborate style in each series as the type style, since it subsumes more of the variations in other styles".

1 In order to avoid confusion in a region forming a geographical and archaeological unit, we have thought it necessary to keep to the terminology indicated by the most recent trends in the archaeology of that region, mainly based on CRUXENT \& RoUSE's publication. 
ARCHAEOLOGY OF THE NETHERLANDS ANTILLES: I

\section{ABSOLUTE CHRONOLOGY}

\begin{tabular}{|c|c|c|c|c|}
\hline \multirow{2}{*}{ Periods } & \multirow{2}{*}{$\begin{array}{c}\text { Dates based } \\
\text { upon Rate of } \\
\text { Refuse } \\
\text { Accumulation }\end{array}$} & \multirow{2}{*}{$\begin{array}{l}\text { Dates based } \\
\text { upon Glotto- } \\
\text { chronology }\end{array}$} & \multicolumn{2}{|c|}{$\begin{array}{l}\text { Dates based upon Radio- } \\
\text { carbon Analysis }\end{array}$} \\
\hline & & & $\begin{array}{l}\text { Calendar } \\
\text { Dates }\end{array}$ & $\begin{array}{l}\text { Dates before } \\
\text { the present }\end{array}$ \\
\hline V & $\begin{array}{l}\text { I500 A.D. } \\
\text { on }\end{array}$ & $\begin{array}{l}\text { I500 A.D. } \\
\text { on }\end{array}$ & $\begin{array}{l}\text { I500 A.D. } \\
\text { on }\end{array}$ & $\begin{array}{l}\mathrm{O}- \\
45^{\circ} \text { B.P. }\end{array}$ \\
\hline IV & $\begin{array}{l}\text { I437- } \\
\text { I500 A.D. }\end{array}$ & $\begin{array}{l}\text { I350- } \\
\text { I500 A.D. }\end{array}$ & $\begin{array}{l}\text { II50- } \\
\text { I500 A.D. }\end{array}$ & $\begin{array}{l}45^{\circ}- \\
800 \text { B.P. }\end{array}$ \\
\hline III & $\begin{array}{l}\text { II93- } \\
\text { I437 A.D. }\end{array}$ & $\begin{array}{l}75^{\circ}- \\
\text { I350 A.D. }\end{array}$ & $\begin{array}{l}35^{\circ}- \\
\text { II50 A.D. }\end{array}$ & $\begin{array}{l}800- \\
\text { I60o B.P. }\end{array}$ \\
\hline II & $\begin{array}{l}929- \\
\text { II93 A.D. }\end{array}$ & $\begin{array}{l}\text { I50- } \\
75^{\circ} \text { A.D. }\end{array}$ & $\begin{array}{l}\text { B.C. I050- } \\
350 \text { A.D. }\end{array}$ & $\begin{array}{l}\text { I600- } \\
3000 \text { B.P. }\end{array}$ \\
\hline I & $\begin{array}{l}849- \\
929 \text { A.D. }\end{array}$ & $\begin{array}{l}\text { B.C. } 50- \\
\text { I50 A.D. }\end{array}$ & $\begin{array}{l}\text { B.C. } 5050- \\
\text { ro50 }\end{array}$ & $\begin{array}{l}3000- \\
7000 \text { B.P. }\end{array}$ \\
\hline
\end{tabular}

The term 'series', which is in point of fact a collective name covering a series of subordinate styles, originated from the difficulties which arose in comparing pottery ${ }^{1}$; it may be observed that the styles of different regions closely resemble each other, and yet are decidedly not identical.

As the authors themselves suggest in several passages, this grouping into series, which amounts to a first attempt to organize the archaeology of Venezuela in a definite manner, will probably be altered in some details in course of time, as additional archaeological data become available. For instance, we read (CRUXent \& Rouse, I958, p. 23-24): "We suspect that some series may have had more than one place of origin, e.g., that certain of their traits may have originated in one style and have spread in one direction while other traits may have originated in other styles and have spread in different directions."

This shows that certain series may overlap, and that this is not merely a geographical phenomenon, but necessarily also a chronological one, which may have important implications. A site where different hybrid styles were found has been classified

1 The term complex is adopted for classification of non-ceramic sites (Cruxent \& Rouse, 1958, p. 3). 
in the series whose traits appeared to be dominant. We now know (op. cit. p. 73) that the archaeological material from Aruba, Curaçao and Bonaire is contained in what is called the Dabajuroid series, and should be dated as belonging to Periods IV-V, i.e. from II 50 to I500, possibly on to I900 A.D. ${ }^{1}$

Our investigation has shown that most of the archaeological material from the islands should be assigned to Period IV. However, we have a few sherds from Period II, and on the other hand sherds and artifacts from periods down to V.

As witness to this, VAN KoolwIJK (I88I, p. I4) writes about a (Spanish) silver coin in one of his letters to the Director of the National Museum of Antiquities at Leiden: In one of the boxes I sent to the National Museum of Antiquities there is a silver coin, which was found in the neighbourhood of Knopenberg hill (Seroe di Boton) some twenty years ago; there, many discs made from shell are also found.

For the sake of convenience we shall first discuss the few old trade sherds before proceeding to describe the characteristic material from the Aruba area, which at the moment is characterized by two styles, the Santa Cruz style and the Savaneta style both belonging to the Dabajuroid series. Finally, we shall briefly consider Curaçao and Bonaire, which are at least equally important from an archaeological point of view but from which we unfortunately have too little material and data to enable justifiable conclusions to be drawn.

In our Museum there are about 3000 sherds from Aruba (2700 from Santa Cruz and 300 from Savaneta). There are as many from Curaçao, but 98 per cent of these consist of small eroded sherds of a plain ware which would not repay investigation. From Bonaire we have some two hundred sherds, only a few of which can be discussed, for the same reason.

$$
\text { A R U B A (Plate I-XVII, XXIIa) }
$$

Santa Cruz Period II (Plate II)

Of these we have five sherds with a fine-line incised crosshatching decoration. The sherds are grit-tempered, rather thin and hard. There are no traces of painting or finishing with a white paste. They are too small to enable the original shape of

\footnotetext{
1 The term Dabajuroid is derived from Dabajuro, a place in Venezuela not far from the coast, between the Lake of Maracaibo and the Paraguaná peninsula.
} 
the pot to be recognized, but we may assume that they belonged to a type of bowl with sinuous, flaring sides, except one sherd which might be from a pottery disc (cf. ReICHel-Dolmatoff, I956, pl. XIX 2). This kind of pottery is trade ware that probably came from the northeastern part of Venezuela, while it also occurs in Trinidad, near Cedros Bay, where Rouse and BulLBROOK found it in 1946 and from which it has since been known as Cedros-style pottery.

This Cedros-style spread along the north coast of Venezuela via Irapa and El Mayal, as far as Río Guapo. On the other hand pottery has been found with the same sort of fine-line incised cross-hatching at Momil, in northeastern Colombia; the excavator of that site put its age as contemporaneous with the second period in Venezuela (REICHel-DolmatofF, I956, p. 279). Rouse examined the possibility of a relation between Colombia and Venezuela with regard to this crosshatched pottery, and arrived at a negative conclusion, for several reasons (CRUXENT \& Rouse, I958, p. 37).

Anyway, we are more inclined to believe that the Aruba sherds came from northeastern Venezuela than that they came from Colombia, firstly because the Cordilleras de los Andes formed a kind of natural barrier, and secondly because, in addition to the pottery, the other artifacts also show points of connection with the Venezuelan region (cf. van HeEkeren, p. II2). In doing so, we in no way disturb the archaeological order created by Cruxent and Rouse.

The transition from Period II to III is not always quite clear. It is known that at Irapa on the Paria peninsula the Cedros style continues down to Period III, but so far this is the only place where this is known to happen (CRUXENT \& ROUSE, I958, p. I3I). Taking this into account in our dating, we may assign the five trade sherds of the Cedros style found at Santa Cruz, in Aruba, to the end of Period II, i.e. to the third or fourth century A.D.

In addition, we still have a number of sherds (e.g. with red and white painting on a white slip and some serpent motifs) which we can only conjecture to belong to Period II or III, since we have not been able to compare them in any way. When writing this article we only had CRUXENT \& RousE's descriptions in the first part of their Archaeological Chronology of Venezuela to go on, since the second part of their work, which contains the photos, has not yet reached us.

We shall not make any definite pronouncements here con- 
cerning sherds which may belong to Period II or III, except with regard to a few Cedros sherds which were so characteristic that we could recognize them, while, in addition, we had seen pictures of them in an article by CRUXENT (I949, p. I63) on the Guapo site. As has already been remarked, most of the material from Aruba, i.e. more than 90 per cent of it, shows traits typical of Period IV.

It might be expected that, in a small island like Aruba, only one uniform style would be found, which would imply that the material dug up at Santa Cruz might be supposed identical with that of Savaneta. This is decidedly not so, though the pottery from the two sites is, admittedly, very similar. We are therefore obliged to deal with the two sites separately and to classify them in different styles.

\section{Santa Cruz Style (Plate III-XVI).}

During his campaign in I922-23 DE Josselin DE JoNG dug three trenches in the Santa Cruz Area, situated just in the centre of Aruba, on the eastern side of Hooiberg hill (cf. van HeEkEREN, p. Io6-rog).

Trench B he abandoned without taking any archaeological objects from it. From trench $\mathrm{C}$ a number of sherds were obtained which are absolutely identical with those from A; accordingly we thought it advisable to simplify things by generalizing the finds under the heading 'Santa Cruz'.

The deposits seem to be no more than 25 or $50 \mathrm{~cm}$ in height, and cover a rather large area which has not yet been defined. The sherds exhibit remarkable a variety. In the painted ware the clay is rather fine, whereas in the plain types it tends to be coarse. Tempering has been carried out with the aid of grit and shell, but its percentage cannot be determined.

Numerous corrugated rimsherds reveal the coiling method as manufacturing technique. Very often the surfaces are not perfectly smooth, and we see traces of scraping. No polished sherds have been found in this collection. The surface colours vary as a result of badly controlled firing. Lack of oxygen and unintentional smoking have caused large patches of black and gray, while overfiring resulted in stone-reddish areas. Normally the surface colours range from black, gray, brown to red. Fabricimpressed sherds are rare. No Santa Cruz sherds show any sign of use of the paddle-and-anvil finishing technique which occurs 
ARCHAEOLOGY OF THE NETHERLANDS ANTILLES: I 9I

in the Dabajuro style. Very few accurately restorable vessels were found in the present Museum collection, but approximate shapes could be determined from a certain number of rims, large sherds, basal and leg fragments. The basic shapes deduced are: large urns, often used for funeral purposes, as will be seen later; ollas, probably for keeping water; bottles; and bowls.

There are many different sorts of bases. For instance, we found round bottoms and flat bases, annular bases, low stand rings, legs from multipod bowls, leg-ring bases and, finally, a few footshaped objects which might have been either legs of a large vessel or supports of single-legged bowls (Pl. IV). One of these is hollow, and happens to be our finest example, showing the coiling technique (Pl. IV 4). Leg and ring bases (Pl. IV 5, VI 2) do not occur frequently. Perforated annular bases are characteristic of the black-on-white painted ware. A great variety of handles were also found. On the plain ware, horizontal-arched, solid handles, or crescent-shaped ones, are seen. Bitubular handles placed vertically on the vessel wall are common. On one example the double-rodded handle ends in a human face on the inside of the bowl. One sherd has a double-rodded appliqué strip serving as handle.

On the black-on-white painted pottery, handles mostly appear in animal forms, extending vertically across the aperture of the vessel. In the same ware, an especially remarkable type of handle was met with - flat and discoidal, with a flat square lump on its top. A similar piece was found by CRUXENT (I955, p. 9Im22) in the valley of Palo Negro.

Finally, there are a few (9) objects which are considered to be bases with supports; but the human features in coffee-bean elements on one of them would be inverted if the supports were turned upwards. This suggests that we are dealing with handles. They are flat, trapezoidal in form, and slightly curved to follow the circumference of the bowl or dish. They only seem to occur in the polychrome and black-on-red ware, and are hardly ever unaccompanied by appliqué work.

The following types of lugs and ears are distinguishable: small, solid lumps of clay fixed on the vessel wall and then pierced with a needle or pin; tubular ears showing from one to four parallel tubes, often decorated with punctuated strips on the ends; elbow-shaped ears; simple crescent-shaped lugs, placed vertically on the wall; and finally, lugs fixed on the edge of rims and on top of legs. 
There are also lugs or knobs in the shape of an animal's head (Pl. IX 6, X 5). Spouts seem to belong to the painted pottery. There are large ones with a $20 \mathrm{~mm}$ aperture in the black-on-white ware, and small ones with a $5 \mathrm{~mm}$ aperture in the black-on-red ware. They have frequently been modelled with appliqué work, and shaped in zoomorphic forms. Appliqué work decorates vessel walls, legs, handles, lugs, spouts and supports of annular bases. On the latter, owl-like figures can be recognized, with a hooked beak and dotted, encircled eyes. The frog motif and the coffeebean eye are very characteristic. Many human faces are indicated by coffee-bean elements, with strips of clay for eyebrows and even hair. In general, animals are difficult to identify, but bats and serpents can be seen, in addition to those just mentioned. The appliqué designs are frequently notched, punctuated or painted.

Incised pottery is not so well represented at the Santa Cruz site. We encountered only a few small sherds of bowls with broadlined incisions. The incised sherds were all of a red-slipped type.

The different painting styles found in the Santa Cruz collection will now be enumerated in order of frequency, e.g. blackon-white, black-on-red in two types, one with a lustrous red slip and the other with a chalky dull slip, black and red on plain, black and red on tan or red, red-on-white and red-on-red. Several sherds of the black-on-white type have a rather bluish-coloured slip instead of the usual white or yellowish one. Some authors describe these as a separate type (FERIz, I959, p. II9), but in our opinion the effect is due to a discoloration of the slip which was not intentional.

Most of the black-on-white painted sherds are ornamented with appliqué work. The patterns show no naturalistic features; they are purely geometric designs. They consist of painted areas bounded by straight or crudely curved parallel lines, running in horizontal as well as in vertical directions. There are comb-like designs, spirals, volutes, semi-circles, triangels and diaboloshaped designs. There is only one dotted pottery fragment in black-on-white.

Pottery artifacts - Contrary to expectations, six griddle fragments were found; normally, these rarely occur in the Dabajuro series. They are very important for a reconstruction of the economic aspects of the island society (vAN HEEKEREN, p. Iro).

Our collection contained numerous topia or circular clay 
pot remains, the use of which we are unable to explain.

There are three fragments of probably cylindrical stamps with a broad-lined, incised, decorative design. One solid cylindrical stamp seems to be complete. The one pipe stem is not sufficient evidence for local manufacture.

No spindle whorls were found, but perhaps some drilled potsherds did duty for them.

Finally, one object could not be identified (Pl. XV 4). We do not know whether it is an ear-plug, a stamp, or perhaps a spindle whorl.

\section{Savaneta Style (Plate XVII)}

The site of Savaneta is situated on the south coast of Aruba. Professor DE JossELIN DE JoNG dug eight sections there, each one metre square, in which he discerned two levels, from o tot 25 $\mathrm{cm}$ and from 25 to $50 \mathrm{~cm}$. In general the material is similar to that of Santa Cruz. The sherds range from coarse in the plain ware to fine in the painted, with an average thickness of between 4 and ro $\mathrm{mm}$. Both grit and shell tempering occur. The coiling technique is again met with, and is evidenced by numerous corrugated rimsherds. Surfaces are scraped and smoothed. Only one polished sherd has been found.

Hard-baked, grit-tempered sherds of a plain grey-yellowish ware which was lacking on the Santa Cruz site, seem to be characteristic here. The avarage thickness is almost $5 \mathrm{~mm}$.

Fabric impression is evident, and exactly fits the description given by CRUXENT \& Rouse (I958, p. 7I) for the Dabajuro examples: "It is evident in many cases that the fabric has been pressed into a thick slip of soft clay, applied over the smooth, hardened surface of the vessel wall. The impressions usually cover the entire exterior surface of the sherds but are occasionally limited"' (see Pl. XVII 7, cf. III 7).

Firing clouds are common.

Of the approximately 300 sherds from Savaneta, more than 200 are plain, 5I are black-on-red, 29 black-on-white. Hollow rims are rare. The general shapes must have been those of urns and bowls. No bottle necks or collars from jars have been found.

The black-on-red ware includes a few annular bases. In Pl. XVII 5 the bottom of a tripod bowl with broken-off legs is shown. Rings and legs and flat bases are lacking; there is only one example of a single-legged bowl. In the black-on-white painted ware a spherical object, decorated with dotted painting 
and appliqué strips and knobs, attracted special attention (Pl. XVII 9). It might have been the cover of a bottle. Handles, lugs and spouts occur sporadically. The painted designs are similar to those described for the Santa Cruz style.

Unlike the Santa Cruz, the sample from this site is too small to enable important conclusions to be drawn; all that can be said is that the material from Savaneta corresponds closely with that from Santa Cruz. An exception is a thin, hard-baked greyish ware that is lacking on the latter site.

Pottery artifacts are virtually non-existent except for topia and one griddle fragment.

\section{Summary of the Aruban Material}

Most of the material from the two sites of Santa Cruz and Savaneta, which are all that are as yet, seems to fit very well into the Dabajuroid series. The presence of the 'Cedros' sherds indicates that Aruba was inhabited in very remote times. The appearance of this pottery in the second period correlates with the discovery of some shell and bone artifacts, which are characteristic of pre-ceramic cultures whose survival into the ceramic period is not impossible (van HeEkeren, p. II5). As regards the material of Period IV, we would emphasize the preesencee of griddlês, which rârêlyy occuur on sites of the Dabajuroid series (CRUXENT \& Rouse, I958, p. 255-257). The supposed trapezoidal handles are a complete mystery at the moment, because no information is available about similar specimens in the related neighbouring districts.

$$
\text { CURAÇAO (Plate XVIII-XX) }
$$

The archaeological harvest from Curaçao was not so rich as that from Aruba. The sites from which the material was gathered were Westpunt, Knip and Sint Jan all situated in the northwestern part of the island, and Hato and Asiento in the centre, and Santa Barbara in the southeast. The bulk of the material was provided by the St. Jan area. The samples from the different sites are too unimportant for classification in separate styles. We shall therefore give a general view of the whole collection without detailing the provenance of the objects.

The clay has been rather sparsely tempered with small quartz particles. Grit and shell-tempering do not occur so much as in 
Aruba. Some sherds are brittle and of a spongy texture. Surfaces are smoothed and scraped. The main colours are tan, brown and red. There are also the usual firing clouds and reddish overbaked areas. Corrugated rims indicate coiling technique.

The bases found include flat bases, low stand rings, one fragment of a pierced annular base, and quite a number of common annular bases. As at Santa Cruz, there is one fragment of a single-legged bowl (Pl. XVIII 5). Handles are relatively rare. It was surprising to find the peculiar trapezoidal handles with painted and appliqué decoration here again.

Lugs and ears do not seem to be very common either. There are a few single-rodded undecorated ears, and some flat, strapshaped ones with a notched ring on the base. One beautiful fragment represents a pair of rim adornos with birds' heads (cf. KIDDER II, I944, pl. IX 28). Hollow rims are conspicuous by their absence. The difference between Aruba and Curaçao is accentuated in the painting. The black-on-white ware is apparently similar. The polychrome ware, black and red-on-white, occurs frequently. On many of the painted sherds the white slip shows a fine craquelure, probably due to corrosion, which is a characteristic feature of the Curaçao and Bonaire painted ware.

The painting is rather crudely done, and the colours tend to fade quickly. Dotted painting is diagnostic for the Curaçao area. It is also found on the red-on-red, black-on-red and red-on-white painting. Geometric designs show ticked lines and different sorts of parallel line combinations.

Pottery artifacts - Twelve griddle fragments were counted from Curaçao, which proves that they were not occasional or intrusive objects. Circular pottery discs do not occur with the same frequency as on Aruba. There is no evidence of other pottery artifacts.

In summing up the data regarding the two areas previously discussed, it is obvious that the Aruban material is closest to the Dabajuro style, a fact which, however, does not exclude Curaçao from the Dabajuroid series. Tempering, colours, and slip are different in the Curaçao area.

Dotted painting designs are diagnostic for the latter. The two areas have griddles and trapezoidal handles in common. 
BONAIRE (Plate XXI)

The material from Bonaire comes entirely from the Hummelinck collection, and was gathered at the sites of Wanapa, Paloe Lechi and Put Bronswinkel.

A great similarity of traits with those of Curaçao is noticeable. In some cases sherds tend to be very coarse and thick, and heavily tempered with crude particles of quartz and mica. The Bonaire pottery betrays a far from complete mastery of firing technique. Overbaked sherds and firing clouds are common.

The greater part of the collection again consists of plain sherds with flat bases, annular bases, perforated annular bases, one round base, solid legs, and one hollow leg fragment with a turtle's head rising slightly above the aperture of the vessel. Numerous coiled rimsherds indicate coiling technique. The dominant surface colours are buff, red and black. Appliqué work is exhibited by only one sherd. Painting is also rather poor. There are two redon-tan sherds (Pl. XXI Io), one black-on-tan showing a diabolo design, two black-on-white and two red-on-white sherds. We also found a green glazed intrusive sherd, probably of European origin.

No other characteristic fragments require mention.

The associated pottery artifacts consist of two griddles and two cylindrical pottery discs.

Consideration of the three areas prompts the conclusion that Curaçao and Bonaire together form a group sharing similar pottery styles, with some identical traits such as tempering, texture, slip, colours and painting. This hypothesis seems to be confirmed by the stone and shell artifacts (van HEEKEREN, p. II5). From the previous comparisons it is clear that Aruba stands alone and seems more closely related to the mainland of Venezuela. Except for the griddles and trapezoidal handles there is nothing that suggests an intimate contact between Aruba and Curaçao, and this prompts the theory that there might have been an occupation by different Indian tribes in former times. We are not the first to suggest this possibility (TEN KATE, I9I6, p. 544), but such problems can only be solved by further archaeological investigations. 


\section{URN BURIALS}

The high percentage of plain urn sherds forces us to give special attention to the question of burials. However, since not a single burial site on one of the islands has yet been cleared by a specialist, we have to be careful in our interpretations. Various methods of burial can be distinguished. Here we restrict ourselves to discussing only urn burials, because there are no trustworthy indications of other types of burial, a short summary of which will follow.

There is, for instance, burial by simple inhumation in the earth of the whole body, without any protection.

A second possible way of carrying out this type of burial is by covering the corpse, or only the skull, with an inverted urn, a stone or pottery slab, or vessels.

Another form of inhumation consists in the disposal of disarticulated bodies in either of the two ways just mentioned.

Then there is the category of urn burials, which can be divided into three types:

Primary urn burial, i.e. the method of disposal in which the body is placed in an urn in a squatting position.

Secondary urn burial, when an urn contains human remains which do not constitute an entire corpse after reconstruction in other words, when there is evidence of disarticulation.

Multiple urn burial, where remains of more than one person are found together. This, in the nature of the case, is always secondary.

Finally our classification is completed by cremation, of which there is no evidence on our islands.

Our general impression of urn burials in Aruba, Curaçao and Bonaire is that secondary urn burials seem to occur frequently, and that only sporadically there is an indication of primary urn burial.

If vaN KoolwiJK (I882) is to be believed, urn burial was practised till recent times. A very old man from Savonet told him that, as a child, he witnessed the funeral of an Indian woman. The body was sunk into an urn in a squatting position with the head uncovered. Many people were invited and several sheep and goats were killed. 
The fact that the corpse was buried in such a way that the head projected above the rim of the urn is proved to have been normal by the excavation, at the Santa Cruz site, of urns covered by a second one in inverted position (VAN KoolwIJK, I882, p. 224; see also van HEEKEREN, p. IO8-IO9).

This being the only indication of primary urn burial we tried to find some more evidence for secondary urn burial, making a serious effort to distinguish various types of burial urns in order to see whether they can have had any bearing on the funeral rites. From the literature of the subject and a few local reports it is known that human remains were often found in various types of urns, and hence it seems impossible to indicate a prototype of a burial urn.

The fact that burial urns were probably used as water tanks in later periods makes it still more difficult. We cannot accept the suggestion of E. BARTELS, in a local daily paper (Beurs 9 May I95I), who states that burial urns have incurving rims whereas water urns have straight vertical or slightly outwardsloping rims. In our opinion both types were used for funeral purposes.

DE Josselin DE Jong (I9I8, p. 67) mentions an anthropomorphic vessel about which no data were available. It is a bulging collar jar with a human face, indicated by a sinuous haírline and archíng eyebrows in appliqué, while nose and eyes are constituted by the well-known coffee-bean elements (Pl. I). The eyes show a surprizingly modern make-up trick known as the 'oeil-de-biche' line. The nostrils are indicated by two vertical incised lines on a small lump of clay. A black, painted, geometrical design covers the whole surface.

Pottery of this type occurs on the mainland of Venezuela, in the Valencia area, and it is not impossible that such urns were used for secondary urn burial. Regarding this, KIDDER (I944, p. I64) writes: "One of the most characteristic forms of Valencia Red is the bulging neck jar, decorated with a human face in most cases. As Nordenskiöld points out, this type of vessel has an extremely wide distribution in South America, being common in the whole western part of the continent, from northwestern Argentina to Colombia, as well as in Brazilian Guiana and the Amazon area. Such jars are often used as burial urns east of the Andes."

If this is true the shape of the vessel would only permit secondary urn burial, or inhumation of cremation relics. 
The above, being the only data available for a typological survey of burial urns, can help us no further towards solution of the burial problems. At any rate, it is legitimate to suppose that secondary urn burial was prevalent in the islands. Various authors substantiate this opinion.

In his field notes on his Aruban excavations DE JosSELIN DE JoNG mentions several cases of it. Indications of several burials not in urns on Curaçao are given in a report, full of essential detail, by the late H. D. RINGMA (I948-5I; cf. WAGENAAR HumMelincK, I959, p. 84).

BARTELS (I953) reports two cases in the Santa Cruz area.

The latest information has been given by Dr. H. FERIz (I959, p. I03-I04), who carried out archaeological explorations on these islands in 1954 .

In his daily report we read, under May I8th: "Pünktlich holen mich die Herren Weve und Hartog ab. Wir fahren zuerst nach St. Cruz, wo bei einer Sandabgrabung, Seroe Noka genannt, ein etwa $300 \mathrm{~m}^{2}$ grosses indianisches Urnenfeld entdeckt wurde, das jetzt unbegreiflicherweise von Bulldozers verwüstet wird, ohne dass die Regierung eingreifen kann. Es besteht kein Gesetz für Natur- und Monumentenschutz. Bartels scheint bei einem Versuch, das Urnenfeld zu retten, untaktisch vorgegangen zu sein und den Eigentümer des Feldes beleidigt zu haben mit der Folge, dass dieser selbstbewusste "Herr" absichtlich alle Urnen zertrümmern lässt - selbst die, die bei den Abgrabungen noch heil freigelegt werden. Die Urnen liegen etwa $75 \mathrm{~cm}$. unter der Oberfläche in einer lehmigen Sandlage, sind roo|: $50 \mathrm{~cm}$. gross und haben wahrscheinlich zur Bergung von Knochen und Asche verbrannter Leichen gedient.

Die sehr zahlreichen Fragmente zeigen, dass es sich um eiförmige Gefässe mit weiter Offnung aus etwa $2 \mathrm{~cm}$. dickem, grauen, schlecht gebrannten Ton gehandelt hat. Ich sehe noch einige Höhlungen, in denen grosse Graburnen gefunden worden waren, deren Fragmente zusammen mit zerbrochenen und zermalmten Skelett-Teilen verstreut herumliegen."

For detailed information about the human remains on the islands see WAgENAAR HUMMELINCKs 1959 paper and the treatise by TACOMA (1959), where the problem of skull deformation is treated.

\section{SUMMARY}

Comparison of the pottery material from Aruba, Curaçao and Bonaire with that from the mainland of Venezuela reveals a wider expansion of influences than was previously accepted by DE Josselin DE Jong, Nomland and Kidder II, who centred all comparisons in the northwestern part of Venezuela and northeast Colombia. We still consider these regions to be the centre of our cultures, but the extension of direct influences 
seems to go farther eastward, as is confirmed by CRUXENT \& Rouse (I958, p. 73), who place quite a number of sites on Margarita Island and the coast opposite in the Dabajuro series.

Turning west again, some familiar traits are encountered in the Chibcha pottery in the Bogotá region. The centres of cultural development in Venezuela are two in number (CRUXENT \& Rouse, p. 263): one in the west, probably along the east coast of the Lake of Maracaibo, and the other in the Orinoco basin.

The historical, social and economic consequences of this binary classification of cultures will be discussed by my colleague vaN HEEKEREN, in the second paper of this series.

\section{EXPLANATION OF PLATES}

The specimens illustrated in the Plates are all in the National Museum of Ethnology (Rijksmuseum voor Volkenkunde) at Leiden, where they belong variously to the collections made by vaN KOOLWIJK, DE JOSSELIN DE JONG and WAGENAAR HUMMELINCK, which will be referred to as $\mathrm{Kw}$, JJ and WH. Where the measurements are not given, they may be computed by comparison with the scale index $($ in $\mathrm{cm})$. The photographs were taken by Mr. C. Zwanenburg, at the National Museum of Ethnology, Leiden. For the maps I am indebted to Dr. Hummelinck.

\section{REFERENCES}

Bartels, E., 1953. De begrafenis-urnen van Seroe Noka. Beurs- en Nieuwsber. 18.11.1953.

Cruxent, J. M., 1949. Noticia preliminar sobre arqueología del Río Guapo. - Estado Miranda. Memorias Soc. Cienc. Nat. la Salle 9, 24, p. I 45-I70.

CRuxent, J. M., I955. Descripción de una colección arqueológica del municipio Dabajuro, Edo. Falcón (Venezuela). Memorias Soc. Cienc. Nat. la Salle I5 $_{5}$ 4, p. 89-1 13 .

Cruxent, J. M. \& Rouse, Irving, 1958. An Archeological Chronology of Venezuela, I. Social Science Monogr. 6, Pan-Amer. Union, Washington.

Feriz, Hans, 1959. Zwischen Peru und Mexico. Meded. Kon. Inst. Tropen Amsterdam 134, Afd. Anthrop. 63.

HeEkeren, H. R. van, I960. A survey of the non-ceramic artifacts of Aruba, Curaçao and Bonaire. Nieuwe West-Indische Gids, 40, p. 103-120. Also in Uitgaven Natuurwet. Werkgroep Ned. Antillen ro, Curaçao.

Josselin DE JoNG, J. P. B. DE, I918. The praecolumbian and early postcolumbian aboriginal population of Aruba, Curaçao and Bonaire. Intern. Archiv Ethnogr. 24, p. 5I-II4. 
ARCHAEOLOGY OF THE NETHERLANDS ANTILLES: I IOI

Josselin DE Jong, J. P. B. DE, 1920. De beteekenis van het archaeologisch onderzoek op Aruba, Curaçao en Bonaire. West-Indische Gids I vol. 2, p. 317-334.

JosSELIN DE JONG, J. P. B. DE, 1923. The praecolumbian and early postcolumbian aboriginal population of Aruba, Curaçao and Bonaire. Intern Archiv. Ethnogr. 25, p. I-26 - Part I continued. Pottery. (No more parts published.)

KAte, H. TEN, I9I6. Oudheden. Encyclopaedie van Nederlandsch WestIndië, 1914-1917, p. 54I-546.

Kidder II, Alfred, I944. Archaeology of Northwestern Venezuela. Papers Peabody Museum Amer. Archeol. Ethnol., Harvard, 26, no. I.

Kidder II, Alfred, 1948. The Archeology of Venezuela. Handbook of South American Indians, IV, ed. J. H. Steward, Bull. Bureau Amer. Ethnol. 143, p. 413-438.

KoolwiJk, A. J. van, I881. (Correspondence between Van Koolwijk and Leemans: Letter no. 84, p. 14. Archief Rijksmuseum voor Volkenkunde, Leiden.)

KoolwiJk, A. J. VAn, r88I. De Indianen-Caraïben, oorspronkelijke bewoners van Curaçao. Tijdschr. Nederl. Aardrijksk. Genootschap 5, p. 57-68.

KoolwiJk, A. J. van, I882. De Indianen Caraïben van het eiland Aruba (West-Indië). Tijdschr. Nederl. Aardr. Gen. 6, p. 222-229.

Nomland, Gladys Ayer, 1933. Archaeological site of Hato Viejo, Venezuela. Amer. Anthropologist 35, p. 718-741.

Nomland, Gladys Ayer, 1935. New Archaeological Sites from the State of Falcón, Venezuela. Ibero-Americana Ir.

NoRdenskiöld, ERLAND, i93o. L'Archéologie du bassin de l'Amazone. Ars Americana I, Paris.

Osgood, Cornelius, 1943. Excavations at Tocorón, Venezuela. Yale Univ. Public. Anthrop. 29.

Osgood, Cornelius \& Howard, George D., 1943. An Archeological Survey of Venezuela. Yale Univ. Publ. Anthrop. 27.

Reichel-Dolmatoff, Gerardo \& Alicia, r956. Momil: Excavaciones en el Sinu. Revista Colomb. Antrop. 5, p. ro9-333.

Ringma, A. D., 1948-I95I. (Archeologische aantekeningen van Curaçao en Aruba: MS from note book. Archief Rijksmuseum voor Volkenkunde, Leiden.)

Rouse, Irving \& Cruxent, José M. \& Goggin, John M., I958. Absolute chronology in the Caribbean area. Proc. 32 Intern. Congr. Americanists, Copenhagen 1956, p. 508-515.

TAсома, J., 1959. Indian skeletal remains from Aruba. West-Indische Gids 39, p. 95-I 12. - Also in Uitgaven Natuurwet. Werkgroep Ned. Antillen 9. Curaçao. 
IO2 ARCHAEOLOGY OF THE NETHERLANDS ANTILLES: I

WagenaAr Hummelinck, P., 1953. Rotstekeningen van Curaçao, Aruba en Bonaire. (Linear rock designs of Curaçao, Aruba and Bonaire). W. $I$. Gids 34, p. 173-209. - Issued separately in Uitgaven Natuurwet. Werkgroep Ned. Ant. 2.

WagenaAr Hummelinck, P., I957. Rotstekeningen van Curaçao, Aruba en Bonaire. (Linear rock designs of Curaçao, Aruba and Bonaire), II. W.I.Gids 37, p. 93-126. - Uitgaven Natuurwet. Werkgroep Ned. Ant. 6.

WAGenaAR Hummelinck, P., 1959. Indiaanse skeletvondsten op Aruba en Curaçao. (Indian skeletal discoveries in Aruba and Curaçao). W.I.

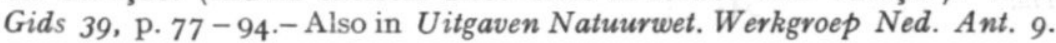

November, 1959. 